\title{
Pollination Requirements of Cicer Milkvetch, Astragalus cicer $\mathrm{L}$.
}

K. W. RICHARDS

Abstract

The effect of bee pollination on seed yield of cicer milkvetch, Astragalus cicer $L$., has not been reported previously for Alberta. The effect of insect pollination was determined by comparing seed yields of open-pollinated and pollinator-excluded plants. It was determined that cicer milkvetch must be cross-pollinated for optimum seed yield, although $1.8 \%$ of the flowers from pollinatorexcluded plant produced pods and seeds. Flowers pollinated within the first 4 days after opening produced more seeds per pod than did flowers pollinated after the fourth day. The actual seed yields with open pollination at 2 locations were only 25.3 and $11.7 \%$ of the mean potential seed yields.

Cicer milkvetch (Astragalus cicer $\mathrm{L}$.) is a relatively new forage legume suitable for use on rangeland and pasture (Johnston et al. 1975) and disturbed land (Holecheck et al. 1982). It is a long-lived, perennial, herbaceous legume with a vigorous, creeping root system. It is not known to cause any physiological problems such as bloat in animals, and its nutritive value for livestock compares favorably with that of alfalfa (Johnston et al. 1975). Because of its potential and the need for seed, the pollination requirements and recommendations for seed production practices need to be established.

Phenotypic diversity of seed-production characteristics exists (Townsend 1971, Smoliak and Johnston 1976), but little is known of the extent to which flowers benefit from insect visits (Scheetz 1971, McGregor 1976). Knowledge of the pollination biology and pollination requirements, whether self-infertile (cross-pollination), self-fertile and partially self-pollinating, or self-fertile and not selfpollinating (Free 1970, McGregor 1976), is a necessary prerequisite to understanding this phenotypic diversity. Knowledge of the pollination requirements can influence the type of breeding program used to improve or develop cultivars and can alter the management of problems such as self-fertility or indeterminate flowering. The number of days that each flower is available for pollination and the mean number of flowers produced per hectare are factors that must be quantified for use in a pollination model (Richards, in prepara-

\footnotetext{
Author is crop entomologist, Agriculture Canada Research Station, Lethbridge, Alberta TIJ 4BI.

Manuscript accepted 6 March 1986.
}

tion) used for predicting the optimum number of pollinators required to pollinate the crop.

This study establishes the extent to which flowers of cicer milkvetch are either self-infertile or self-fertile by comparing raceme and pod seed yields in open-pollinated and pollinator-excluded plants and the influence of flower age and density on seed yield.

\section{Materials and Methods}

The experiments were completed on a Breeder-seed plot of Oxley cicer milkvetch between 1978 and 1982 at the Research Station, Lethbridge, Alberta. The plot, about 0.25 ha, was used in comparisons with a 25-ha commercial Pedigree-seed field of Oxley located at Spring Coulee, Alberta, about $50 \mathrm{~km}$ south of Lethbridge.

Two $1-m^{3}$ cages of fine nylon-mesh screen, which excluded potential pollinators, were placed over a different portion of the crop each year at Lethbridge prior to the commencement of bloom. This isolation provided for evaluation of the capacity for selffertility. All racemes under the cages were hand-harvested when the pods were ripe. Racemes from both cages were combined and 4 subsamples of 25 racemes each were randomly selected.

From the open-pollinated Spring Coulee site and the openpollinated portion of the Lethbridge site, random samples of $\mathbf{4 5 0}$ racemes representing many plants were collected each year. From these, 4 subsamples of 25 racemes each were randomly drawn. The number of flowers available for pollination and the pod and seed sets were determined for the pollinator-excluded and the 2 openpollinated groups of plants. Number of ovules per pod was determined by cutting open newly formed green pods, randomly collected from the Lethbridge plot, and counting the ovules with the aid of a stereomicroscope.

Seed production by age of flower was determined only in 1982 at Lethbridge. Five $1-\mathrm{m}^{3}$ cages of fine nylon-mesh screen were placed over racemes that were about to begin blooming. The lowest flower on a raceme was tagged on the day it opened. For 10 days the lowest flower of a known age from 30 racemes was hand-pollinated with a small paint brush. Pollen was transferred from flowers outside the cages to those inside in order to maximize the opportunity for cross-fertilization. 
Table 1. Characteristics of populations of open-pollinated cicer milkvetch at Spring Coulee and Lethbridge, 1978 to 1982.

\begin{tabular}{|c|c|c|c|c|c|c|c|c|}
\hline \multirow[b]{2}{*}{ Year } & \multicolumn{2}{|c|}{ Flowers/raceme } & \multicolumn{2}{|c|}{ Seed set $(\%)$} & \multicolumn{2}{|c|}{ Seeds/raceme } & \multicolumn{2}{|c|}{ Seeds/pod } \\
\hline & Spring Coulee & Leth. & Spring Coulee & Leth. & Spring Coulee & Leth. & Spring Coulee & Leth. \\
\hline $\begin{array}{l}1978 \\
1979 \\
1980 \\
1981 \\
1982\end{array}$ & $\begin{array}{c}25.3 \pm 0.7 \mathrm{a}^{1} \\
21.3 \pm 0.6 \mathrm{a} \\
23.6 \pm 0.7 \mathrm{a} \\
21.9 \pm 0.5 \mathrm{a} \\
\mathrm{ND}^{2}\end{array}$ & $\begin{array}{l}23.9 \pm 0.8 \mathrm{a} \\
29.7 \pm 0.8 \mathrm{a} \\
25.4 \pm 0.7 \mathrm{a} \\
26.9 \pm 0.8 \mathrm{a} \\
25.7 \pm 0.7 \mathrm{a}\end{array}$ & $\begin{array}{l}80.0 \pm 8.0 \mathrm{a} \\
60.9 \pm 10.4 \mathrm{bc} \\
51.2 \pm 10.3 \mathrm{c} \\
70.6 \pm 9.4 \mathrm{ab} \\
\text { ND }\end{array}$ & $\begin{array}{l}76.5 \pm 8.7 \mathrm{a} \\
67.0 \pm 8.6 \mathrm{a} \\
69.8 \pm 9.1 \mathrm{a} \\
71.8 \pm 8.7 \mathrm{a} \\
70.5 \pm 9.0 \mathrm{a}\end{array}$ & $\begin{array}{r}120.7 \pm 5.3 \mathrm{a} \\
54.2 \pm 4.3 \mathrm{~b} \\
40.5 \pm 2.1 \mathrm{~b} \\
79.6 \pm 4.2 \mathrm{~b} \\
\text { ND }\end{array}$ & $\begin{array}{r}77.6 \pm 3.7 \mathrm{~b} \\
118.2 \pm 6.9 \mathrm{a} \\
94.6 \pm 4.7 \mathrm{a} \\
101.4 \pm 5.0 \mathrm{a} \\
98.2 \pm 4.4 \mathrm{a}\end{array}$ & $\begin{array}{c}5.7 \pm 0.2 \mathrm{a} \\
4.2 \pm 0.3 \mathrm{~b} \\
3.2 \pm 0.2 \mathrm{c} \\
5.1 \pm 0.3 \mathrm{a} \\
\text { ND }\end{array}$ & $\begin{array}{l}4.2 \pm 0.2 b \\
6.0 \pm 0.3 \mathrm{a} \\
5.3 \pm 0.2 \mathrm{a} \\
5.2 \pm 0.2 \mathrm{a} \\
5.4 \pm 0.3 \mathrm{a}\end{array}$ \\
\hline Average & $23.0 \pm 0.3$ & $26.3 \pm 0.4$ & $65.7 \pm 9.9$ & $71.1 \pm 8.8$ & $73.3 \pm 2.6$ & $98.0 \pm 2.7$ & $4.6 \pm 0.1$ & $5.2 \pm 0.1$ \\
\hline
\end{tabular}

'Means \pm SE within a column followed by the same letter do not differ $(P<0.05)$.

2No data.

The number of racemes per area was determined for the Lethbridge and Spring Coulee plots for 1980 and 1981 by counting racemes in $251-\mathrm{m}^{2}$ sample plots. The plots were chosen at random and the counts were made prior to seed harvest. Between-year and location comparisons of data were made using the single classification ANOVA (Model I) (Sokal and Rohlf 1969).

Estimates of the mean number of flowers per hectare available for pollination during the summer and the possible mean seed yield were calculated by the linear model:

$$
X=(a)(b)(c) \text { and } Y=(X)(d)(e)(f)
$$

where $X=$ mean number of flowers $/ \mathrm{ha} ; \mathrm{a}=$ mean number of racemes $/ \mathrm{m}^{2} ; b=$ mean number of flowers $/$ raceme; $c=10,000 \mathrm{~m}^{2} / \mathrm{ha}$;

and where $\mathrm{Y}=$ possible mean seed yield $(\mathrm{kg} / \mathrm{ha}) ; \mathrm{d}=$ mean seeds $/$ pod; $\mathrm{e}=$ pods $/$ flower; constant $=1$, assuming $100 \%$ seed set; $f=$ mean weight $/$ seed, constant (Smoliak and Johnston 1976) $=3.64 \times 10^{-6} \mathrm{~kg} / \mathrm{seed}$.

The data were summarized and subjected to analysis of variance, and Tukey's honestly significant difference procedure (Sokal and Rohlf 1969) was used to detect differences among years for the open-pollinated plots and the pollinator-excluded racemes. The data for over-years comparisons of racemes between the openpollinated plots and the open-pollinated versus pollinator-excluded racemes were pooled to provide a measure of central tendency and to increase the degrees of freedom (Sokal and Rohlf 1969), and were subjected to analysis of variance.

\section{Results and Discussion}

The number of flowers on each axillary, indeterminate raceme of cicer milkvetch ranged from 5 to 56 . Averaged over years, the number of flowers per raceme on the open-pollinated plants was greater $(P<0.05)$ at Lethbridge than at Spring Coulee (Table 1). There was no significant difference in the mean number of flowers per raceme among years at each location.

Averaged over years, the number of flowers producing seeds, i.e., percent seed set, was similar $(P>0.05)$ for both locations. The among-year variation in mean percent seed set was greater at Spring Coulee than at Lethbridge (Table 1). Averaged over years, the number of seeds per raceme and the number of seeds per pod was greater $(P<0.05)$ at Lethbridge than at Spring Coulee. The among-year variation in mean number of seeds per raceme and pod was greater at Spring Coulee than at Lethbridge (Table 1). The mean number of ovules per immature green seed pod was $9.9 \pm 0.1$ (range 2 to $13, n=155$ ). Thus, the number of seeds per pod reaching maturity (5.2) was about half. In comparison, in Colorado, openpollination seed set from 22 accessions was distributed normally between 100 and 300 seeds per raceme with the 176- to 200-seed class per raceme being the most frequent in an analysis of 268 plants (Townsend 1971).

The differences in flowers per raceme, seeds per raceme, and seeds per pod between the 2 locations could be the result of differences in soil types and environmental factors. The small Lethbridge plot had a uniform clay loam soil type throughout and abundant subsoil moisture. Compared with the Spring Coulee location, the average April to September degree-days above $5.0^{\circ} \mathrm{C}$ were higher at Lethbridge $(1,487$ vs. 1,612$)$, there were fewer competing weeds, and plants began flowering about 10 to 14 days earlier.

Differences between the 2 locations in percent seed set and seeds per raceme or pod are likely due to differences in the density and diversity of the pollinators (data not shown). At Lethbridge, honey bees comprised $68 \%$ of the pollinators foraging on the crop, bumble bees $21 \%$, and leafcutter bees $11 \%$, while at Spring Coulee the proportions were $16 \%, 63 \%$, and $21 \%$, respectively. Since natural bee populations are greatly influenced by numerous factors including weather conditions, availability of suitable nesting sites, and parasites or predators, the proportions of native bees on the crop varied from year to year. The variation in proportion of efficiency and effectiveness of these pollinators may explain part of the greater yearly variability in seed production at Spring Coulee.

Averaged over the 5 years, the number of flowers per raceme was similar $(P>0.05)$ on open-pollinated and pollinator-excluded plants (Table 2). Flowers exposed to pollinators had a higher $(P<0.001)$ level of seed set and more seeds per raceme and pod than flowers not exposed to pollinators (Table 2). This indicates that cicer milkvetch, like most other forage legumes, benefits by crosspollination, i.e., is receptive to pollen from other flowers or plants. However, there is a small degree of self-fertility as indicated by the production of seeds under cages. The low number of seeds per pod and raceme on the pollinator-excluded plants may have resulted from a low germination rate of pollen grains, from pollen grains that produced short pollen tube growth and hence did not reach the ovules in the ovary, or from an abnormally high abortion rate of ovules. These are common reasons for low self-fertility in other forage legumes (McGregor 1976). Also, the nylon mesh of the cage would have reduced the amount of light reaching the plants and thus may have reduced seed yield.

In a study of the cross- and self-fertility of the cicer milkvetch cultivar Lutana, Scheetz (1971) estimated $61.8 \%$ flowers producing pods and 5.9 seeds per pod in an open-pollinated plant. His selffertility estimates of $9.3 \%$ flowers producing pods and 1.6 seeds per pod were for plants artificially selfed by hand.

Individual flowers were available for pollination for as long as 7 days. Flowers pollinated within the first 4 days after opening produced about the same amount of seeds per pod (Fig. 1). Flowers pollinated after 4 days produced progressively fewer seeds per pod. Therefore, in order to obtain a high seed yield it is important to have sufficient pollinators on the crop so that most flowers are pollinated within the first 4 days of opening.

The number of racemes per square metre at Lethbridge was greater $(P<0.01)$ than at Spring Coulee for both years (Table 3). There was no significant difference between years at each location.

Using the linear model and the yearly averages (Tables $1,2,3$ ), the mean number of flowers per hectare available for pollination was estimated to be $140.6 \times 10^{6}$ at Lethbridge and $80.4 \times 10^{6}$ at Spring Coulee. An estimate of the maximum potential seed yield 
Table 2. Characteristics of racemes of open-pollated and pollinator-excluded cicer milkvetch at Lethbridge, 1978 to 1982.

\begin{tabular}{|c|c|c|c|c|c|c|c|}
\hline & \multirow{3}{*}{$\begin{array}{c}\text { Open pollinated } \\
\begin{array}{c}\text { 5-yr average } \\
1978 \text { to } 1982\end{array}\end{array}$} & \multicolumn{6}{|c|}{ Pollinators excluded } \\
\hline & & \multirow{2}{*}{$\begin{array}{l}\text { 5-yr, average } \\
1978 \text { to } 1982\end{array}$} & \multirow[b]{2}{*}{1978} & \multicolumn{2}{|c|}{ Annual averages } & \multirow[b]{2}{*}{1981} & \multirow[b]{2}{*}{1982} \\
\hline & & & & 1979 & 1980 & & \\
\hline $\begin{array}{l}\text { Flowers/raceme } \\
\text { Seed set (\%) } \\
\text { Seeds/raceme } \\
\text { Seeds/pod }\end{array}$ & $\begin{array}{c}26.3 \pm 0.41 \\
71.1 \pm 8.8 \\
98.0 \pm 2.7 \\
5.2 \pm 0.1\end{array}$ & $\begin{array}{r}27.1 \pm 0.5 \\
1.8 \pm 2.6 \\
2.7 \pm 0.1 \\
1.8 \pm 0.1\end{array}$ & $\begin{array}{l}31.2 \pm 2.0 \mathrm{a} \\
1.2 \pm 1.9 \mathrm{a} \\
4.2 \pm 0.3 \mathrm{a} \\
2.4 \pm 0.2 \mathrm{a}\end{array}$ & $\begin{array}{c}30.8 \pm 1.6 \mathrm{ab} \\
0.8 \pm 1.6 \mathrm{a} \\
2.8 \pm 0.2 \mathrm{a} \\
1.5 \pm 0.1 \mathrm{~b}\end{array}$ & $\begin{array}{c}27.5 \pm 0.8 \mathrm{ab} \\
2.4 \pm 2.9 \mathrm{a} \\
3.7 \pm 0.2 \mathrm{a} \\
1.7 \pm 0.2 \mathrm{~b}\end{array}$ & $\begin{array}{c}23.3 \pm 0.7 \mathrm{ab} \\
2.5 \pm 3.2 \mathrm{a} \\
2.1 \pm 0.1 \mathrm{a} \\
1.5 \pm 0.2 \mathrm{~b}\end{array}$ & $\begin{array}{c}22.8 \pm 0.8 \mathrm{~b} \\
2.0 \pm 2.9 \mathrm{a} \\
0.8 \pm 0.1 \mathrm{~b} \\
1.8 \pm 0.2 \mathrm{ab}\end{array}$ \\
\hline
\end{tabular}

${ }_{1}$ Mean $\pm \mathrm{SE}$ within a row followed by the same letter do not differ $(R<0.05)$.

assuming $100 \%$ pollination is $2,661 \mathrm{~kg} /$ ha at Lethbridge and 1,346 $\mathrm{kg} / \mathrm{ha}$ at Spring Coulee. An estimate of the mean potential seed yield with $71.1 \%$ of flowers producing pods is $1,892 \mathrm{~kg} / \mathrm{ha}$ at Lethbridge and, with $65.7 \%$ of flowers producing pods, is 884 $\mathrm{kg} / \mathrm{ha}$ at Spring Coulee. The actual seed yields at Lethbridge (mean for 1979 to 1983 was $478 \mathrm{~kg} / \mathrm{ha}$, range $305-725 \mathrm{~kg} / \mathrm{ha}$ ) and at

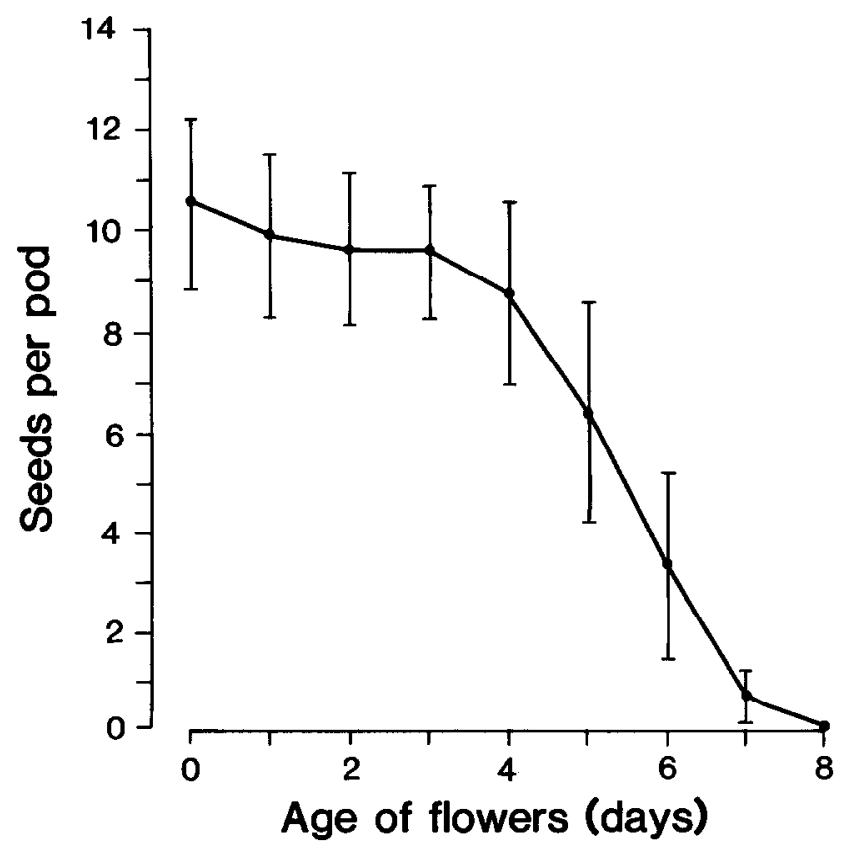

Fig. 1. Seed set (mean $\pm S E$ ) as influenced by the length of time (age of flowers) that flowers of cicer milkvetch are available for pollination.

Spring Coulee (mean for 1978 to 1981 was $103 \mathrm{~kg}$ / ha, range 57-194 $\mathrm{kg} / \mathrm{ha}$ ) were only 25.3 and $11.7 \%$, respectively, of the mean potential seed yields. This significant difference in yield was probably due to incorrect settings of the combine, to combining damp and leathery pods, which resulted in seeds remaining in the flattened pods when threshed, and to a yield loss of about one-third when the
Table 3. The number of racemes per square metre in populations of cicer milkvetch at Spring Coulee and Lethbridge.

\begin{tabular}{lccccccccc}
\hline \hline & \multicolumn{3}{c}{ Lethbridge } & & \multicolumn{3}{c}{ Spring Coulee } \\
\cline { 2 - 4 } \cline { 7 - 9 } Year & $\bar{X}$ & SE & Gl & G2 & & $\bar{X}$ & SE & Gl & G2 \\
\hline 1980 & $544.3 \pm 130.1$ & 0.18 & 2.63 & & $349.2 \pm 165.6$ & 0.65 & 2.75 \\
1981 & $525.0 \pm 138.5$ & -0.42 & 2.63 & & $349.6 \pm 124.1$ & -0.39 & 2.30 \\
\hline
\end{tabular}

$I G 1$ and $G 2=$ measures of skewness and kurtosis

seed was cleaned to purity standards and to small seed separated during sieving. The difference between potential and actual seed yield suggests that improved or new management techniques for harvesting the seed are needed.

Flowers exposed to a variety of pollinators had significantly increased raceme and pod seed production compared with pollinatorexcluded flowers. Thus cicer milkvetch must be cross-pollinated for optimum seed yield. Age of flower when pollinated and flower density also influence possible seed yield. To increase seed yields and economic benefits, seed growers should ensure that there are sufficient numbers of domesticated pollinators to visit most flowers in cicer milkvetch fields.

\section{Literature Cited}

Free, J.B. 1970. Insect pollination of crops. Academic Press, New York.

Holecheck, J.L., E.J. De Puit, J.G. Coenenbers, and R. Valdez. 1982. Legume establishment on strip-mined lands in southeastern Montana. J. Range Manage. 35:298-300.

Johnston, A., S. Smoliak, M.R. Hanna, and R. Hironaka. 1975. Cicer milkvetch for western Canada. Can. Agr. Pub. 1536.

McGregor, S.E. 1976. Insect pollination of cultivated crop plants. Agr. Handbook No. 496. ARS USDA.

Scheetz, J.G. 1971. Estimates of cross- and self-fertility of cicer milkvetch (Astragalus cicer L.). Unpub. M.Sc. Thesis, Montana State Univ.

Smoliak, S., and A. Johnston. 1976. Variability in forage and seed production and seedling growth in Astragalus cicer. Can. J. Plant Sci. 56:487-491.

Sokal, R.R., and F.J. Rohlf. 1969. Biometry. W.H. Freeman, San Francisco.

Townsend, C.E. 1971. Association among characters related to seed production in Astragalus cicer L. Crop Sci. 11:307-308. 